\title{
Evaluation of Risk Parity Asset Allocation Strategy in Indonesia Mutual Fund During 2010-2019 Period
}

\author{
Wayan Mahendra Kurniawan, and Erman Sumirat
}

\begin{abstract}
Indonesia as the largest country in Southeast Asia have the highest GDP among the other countries in the region. In 2011, McKinsey \& Company conducted a research to understand the annual consumer spending trend in Indonesia. According to the research, financial services will be the main consumption in Indonesia in 2030. Despite those promising situations, mutual fund industry in Indonesia was facing a big challenge in 2019. During 2019, Indonesia Financial Authority (OJK) has suspended 37 mismanaged mutual fund products from several investment managers. And actively managed mutual funds will have more exposure on this mismanagement risk.
\end{abstract}

Aside from mismanagement and underperforming risk of actively managed mutual fund, investor also facing high risk of equity asset class. Recently, IDX Composite (IHSG) experience a tremendous $\mathbf{- 2 8 \%}$ drop in Q1 2020 . Biggest peak to bottom drawdown during that period was $-37,49 \%$ from 14 January 2020 until 24 March 2020. This situation creates a challenge for mutual fund sales agent (APERD).

But a challenging situation also offers opportunities. Mutual fund sales agent (APERD) that can offer optimum asset allocation suggestion that can give maximum risk protection can take advantage of these situation. One such unique strategy that has not been applied by other mutual fund sales agent (APERD) is risk parity that became popular after 2008 financial crisis.

This research applied risk parity framework in passively managed mutual fund because most of actively managed mutual funds in Indonesia underperform the benchmark in the 10-year period. Because of that, passively managed mutual funds provide better investment opportunity. Four equity indexes (LQ45, Jakarta Islamic Index, Bisnis 27, and Sri Kehati) and one passively managed fixed income mutual fund (ABF Indonesia Bond Index Fund) that have existed for 10year period was chosen to apply the risk parity method. Sharpe ratio calculation is used to evaluate the portfolio performance compared to commonly used portfolio strategy in the world according to 2018 Legg Mason Global Investment Survey.

Result of the analysis is that risk parity portfolio offer better Sharpe ratio compared to commonly used portfolio strategy in the world. Result of 2009 - April 2020 back-testing process also show that risk parity can protect investor from equity market downturn in $77.3 \%$ of the case. With above result, risk parity can offer better risk protection for Indonesia individual investor.

Index Terms - Markowitz Portfolio Theory, Mutual Fund, Sharpe Ratio.

\section{INTRODUCTION}

Indonesia as the largest country in Southeast Asia have the highest GDP among the other countries in the region. In 2011, McKinsey \& Company conducted a research to understand the annual consumer spending trend in Indonesia. According to the research, financial services will be the main consumption in Indonesia in 2030. Projected consumer spending in financial service will be around 565 billion US Dollar. Projected growth from 2010 to 2030 in this segment was around 10,5\% CAGR [12].

In line with that research, 2018 Annual Report of Indonesia Stock Exchange (BEI) also shown significant growth in number of investors from 2012 to 2018, with 55\% CAGR from 2015 to 2018. Most of the registered SID in KSEI is for mutual fund SID [6].

Despite those promising situations, mutual fund industry in Indonesia was facing a big challenge in 2019. Many mutual funds have been suspended by Indonesia Financial Authority (OJK). During 2019, Indonesia Financial Authority (OJK) has suspended 37 mutual fund products from several investment managers [13]. And actively managed mutual funds will have more exposure on this mismanagement risk.

Not only mismanagement risk, but also underperformance risk of actively managed mutual funds needs to be considered. S\&P 500 published a benchmark that over the long run, actively managed mutual fund in U.S. failed to beat the market index by a large percentage [9].

Aside from mismanagement and underperforming risk of actively managed mutual fund, investor also facing high risk of equity asset class. Recently, IDX Composite (IHSG) experience a tremendous $-28 \%$ return in Q1 2020. Biggest peak to bottom drawdown during that period was $-37,49 \%$ from 14 January 2020 until 24 March 2020 [1].

But a challenging situation also offers opportunities. Mutual fund sales agent (APERD) that can offer optimum asset allocation suggestion that match with Indonesia investor's risk aversity profile and can give maximum risk protection can take advantage of those situation and attract fearful customer.

One unique strategy that has not been applied by other mutual fund sales agent (APERD) is risk parity.

\section{LITERATURE REVIEW}

\section{A. Actively Managed Mutual Fund Performance}

S\&P 500 published SPIVA report benchmark showing that over the long run, actively managed mutual fund in U.S. failed to beat the market index by a large percentage [9]. 
With that situation, it seems that passively managed mutual funds that only aim to match the index performance sounds like a better investment solution to minimize the mismanagement and underperforming risk.

\section{B. Risk Parity Asset Allocation}

The central idea of the risk parity approach is that in a well-diversified portfolio all asset classes should have the same marginal contribution to the total risk of the portfolio [8]. The marginal contributions of the two assets to the total risk of the portfolio are:

$$
\begin{aligned}
& M C_{1}=w_{1} \times\left(\frac{\Delta \sigma\left[R_{p}\right]}{\Delta w_{1}}\right)=w_{1} \times\left(\frac{w_{1} \sigma\left[R_{1}\right]^{2}+w_{2} \operatorname{Cov}\left[R_{1} \cdot R_{2}\right]}{\sigma\left[R_{p}\right]}\right) \\
& M C_{2}=w_{2} \times\left(\frac{\Delta \sigma\left[R_{p}\right]}{\Delta w_{2}}\right)=w_{1} \times\left(\frac{w_{2} \sigma\left[R_{2}\right]^{2}+w_{1} \operatorname{Cov}\left[R_{1} \cdot R_{2}\right]}{\sigma\left[R_{p}\right]}\right)
\end{aligned}
$$

The rate of return and the standard deviation of the rate of return on this portfolio, E[R_p] and $\sigma\left[R \_p\right]$ :

$$
\begin{aligned}
& E\left[R_{p}\right]=w_{1} E\left[R_{1}\right]+w_{2} E\left[R_{2}\right] \\
& \sigma\left[R_{p}\right]=\sqrt{w_{1}^{2} \sigma\left[R_{1}\right]^{2}+w_{2}^{2} \sigma\left[R_{2}\right]^{2}+2 w_{1} w_{2} \operatorname{Cov}\left[R_{1} \cdot R_{2}\right]}
\end{aligned}
$$

\section{Methodology}

Conceptual Framework

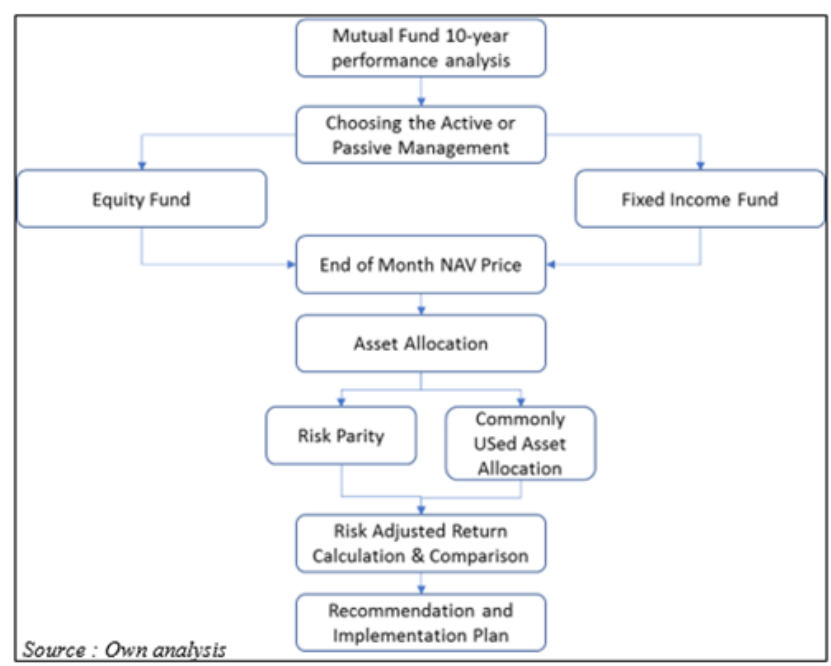

Fig. 1. Conceptual Framework.

Type of mutual fund that will be analyzed depends on the last 10-years yearly period (2009-2019). 10 years yearly performance has been chosen because according to yearly historical return of IDX Composite (IHSG), 10-year investment period was the minimum period to get $100 \%$ chance of positive return. If more than $50 \%$ of available actively managed funds that have already existed for the past 10 years yearly period can outperform the benchmark in the 10 years yearly period, application of risk parity will be applied to those actively managed mutual funds. If less than $50 \%$ of available actively managed funds that have already existed for the past 10 years yearly period can outperform the benchmark in the 10 years yearly period, application of risk parity will be applied to Indonesia Stock Exchange's index value.
Some selection criteria need to be applied in available passively managed mutual funds in Indonesia to have performance that can replicate as close as possible IDX Composite (IHSG) performance.

1. Has available investment products with the form of passively managed mutual funds.

2. The index has already existed for the past 10 years yearly period

Yearly geometrical return and standard deviation will be calculated using those mutual funds' NAV downloaded from pasardana.id. Risk parity asset allocation method will then be used to construct the risk parity portfolio using the help of Solver function from Microsoft Excel. Sharpe ratio of risk parity portfolio will be compared to commonly used asset allocation strategy among individual investor in the world to see which asset allocation has the best risk-adjusted return performance.

\section{FINDINGS AND ARGUMENTS}

\section{A. Indonesia Actively Managed Mutual Fund Performance}

From data analysis result, majority of the actively managed mutual funds hardly able to outperform the index. $94 \%$ of actively managed equity mutual funds underperform IDX Composite (IHSG) and $97 \%$ of actively managed fixed income mutual funds underperform Indonesia Composite Bond Index (ICBI). Investor will get better performance by investing in passively managed mutual funds that aim to match the index performance.

From above selection criteria explained in the methodology section, four equity indexes (LQ45, Bisnis-27, JII, and Sri Kehati) and one index fixed income mutual fund (Bahana ABF Indonesia Bond Index Fund) used to implement the risk parity framework [7].

\section{B. Risk Parity Asset Allocation}

Below is yearly return and risk (standard deviation) of each asset class and covariance between those two asset classes will be calculated using monthly return for 10 -year yearly period (2009-2019).

TABLE 1: HISTORICAL RISK, RETURN, AND COVARIANCE SOURCE: PASARDANA.ID, OWN ANALYSIS LQ 45 \& ABF Indonesia Bond Index Fund

\begin{tabular}{|c|c|c|}
\hline & LQ45 & ABF Indonesia Bond \\
\hline Monthly Return & $0.58 \%$ & $0.72 \%$ \\
\hline $\begin{array}{c}\text { Annualized } \\
\text { Return }\end{array}$ & $7.16 \%$ & $8.98 \%$ \\
\hline Monthly Stdev & $4.33 \%$ & $2.40 \%$ \\
\hline $\begin{array}{c}\text { Annualized } \\
\text { Stdev }\end{array}$ & $14.98 \%$ & $8.31 \%$ \\
\hline Covariance & 0.000618 & 0.000618129 \\
\hline
\end{tabular}

Bisnis 27 \& ABF Indonesia Bond Index Fund

\begin{tabular}{|c|c|c|}
\multicolumn{3}{|c|}{ Bispis 27 \& ABF Indonesia Bond Index Fund } \\
\hline & Bisnis 27 & ABF Indonesia Bond \\
\hline Monthly Return & $0.70 \%$ & $0.72 \%$ \\
\hline $\begin{array}{c}\text { Annualized } \\
\text { Return }\end{array}$ & $8.79 \%$ & $8.98 \%$ \\
\hline Monthly Stdex & $4.56 \%$ & $2.40 \%$ \\
\hline $\begin{array}{c}\text { Annualized } \\
\text { Stdev }\end{array}$ & $15.80 \%$ & $8.31 \%$ \\
\hline Covariance & 0.000066 & 0.000066 \\
\hline
\end{tabular}


JII \& ABF Indonesia Bond Index Fund

\begin{tabular}{|c|c|c|}
\hline & JII & ABF Indonesia Bond \\
\hline Monthly Return & $0.43 \%$ & $0.72 \%$ \\
\hline $\begin{array}{c}\text { Annualized } \\
\text { Return }\end{array}$ & $5.28 \%$ & $8.98 \%$ \\
\hline Monthly Stdev & $4.06 \%$ & $2.40 \%$ \\
\hline $\begin{array}{c}\text { Annualized } \\
\text { Stdev }\end{array}$ & $14.07 \%$ & $8.31 \%$ \\
\hline Covariance & 0.000543604 & 0.000543604 \\
\hline
\end{tabular}

Sri Kehati \& ABF Indonesia Bond Index Fund

\begin{tabular}{|c|c|c|}
\hline & Sri Kehati & ABF Indonesia Bond \\
\hline Monthly Return & $0.84 \%$ & $0.72 \%$ \\
\hline $\begin{array}{c}\text { Annualized } \\
\text { Return }\end{array}$ & $10.59 \%$ & $8.98 \%$ \\
\hline Monthly Stdev & $4.37 \%$ & $2.40 \%$ \\
\hline $\begin{array}{c}\text { Annualized } \\
\text { Stdev }\end{array}$ & $15.13 \%$ & $8.31 \%$ \\
\hline Covariance & 0.000618081 & 0.000618081 \\
\hline
\end{tabular}

Below is the result of Risk Parity application in above portfolio.

TABLE 2: Risk PARITY ASSET ALLOCATION RESUlT

\begin{tabular}{|l|c|c|}
\hline & LQ45 & ABF Indonesia Bond \\
\hline Capital Allocation & $35.67 \%$ & $64.33 \%$ \\
\hline Total Weight & \multicolumn{2}{|c|}{$100.00 \%$} \\
\hline MC & $3.87 \%$ & $3.87 \%$ \\
\hline Portfolio Risk & \multicolumn{2}{|c|}{$\mathbf{7 . 7 4 \%}$} \\
\hline Portfolio Return & \multicolumn{2}{|c|}{$\mathbf{8 . 3 3 \%}$} \\
\hline
\end{tabular}

\begin{tabular}{|l|c|c|}
\hline & Bisnis 27 & ABF Indonesia Bond \\
\hline Capital Allocation & $34.46 \%$ & $65.54 \%$ \\
\hline Total Weight & \multicolumn{2}{|c|}{$100.00 \%$} \\
\hline MC & $3.86 \%$ & $3.86 \%$ \\
\hline Portfolio Risk & \multicolumn{2}{|c|}{$\mathbf{7 . 7 2 \%}$} \\
\hline Portfolio Return & \multicolumn{2}{|c|}{$\mathbf{8 . 9 2 \%}$} \\
\hline
\end{tabular}

\begin{tabular}{|l|c|c|}
\hline & JII & ABF Indonesia Bond \\
\hline Capital Allocation & $37.13 \%$ & $62.87 \%$ \\
\hline Total Weight & \multicolumn{2}{|c|}{$100.00 \%$} \\
\hline MC & $3.78 \%$ & $3.78 \%$ \\
\hline Portfolio Risk & \multicolumn{2}{|c|}{$7.56 \%$} \\
\hline Portfolio Return & \multicolumn{2}{|c|}{$7.61 \%$} \\
\hline
\end{tabular}

\begin{tabular}{|l|c|c|}
\hline & Sri Kehati & ABF Indonesia Bond \\
\hline Capital Allocation & $35.46 \%$ & $64.54 \%$ \\
\hline Total Weight & \multicolumn{2}{|c|}{$100.00 \%$} \\
\hline MC & $3.88 \%$ & $3.88 \%$ \\
\hline Portfolio Risk & \multicolumn{2}{|c|}{$7.77 \%$} \\
\hline Portfolio Return & \multicolumn{2}{|c|}{$9.55 \%$} \\
\hline
\end{tabular}

Source: pasardana.id, own analysis.

\section{Sharpe Ratio Analysis}

Performance of risk parity asset allocation strategy then compared to commonly used asset allocation of individual investor in the world according to Legg Mason Investment Management [9]. Most popular equity - fixed income asset allocation globally is $58 \%-42 \%$, Europe is $60 \%-40 \%$, Asia is $61 \%-39 \%$, and US is $57 \%-43 \%$. Risk Parity asset allocation method have better risk-adjusted performance compared to commonly used asset allocation method in the world.
TABLE 3: SHARPE RATIO COMPARISON

\begin{tabular}{|c|c|c|c|c|c|}
\hline Sharpe Ratio Comparison & Risk Parity & Global & Europe & Asia & US \\
\hline LQ45 - ABF Indonesia Bond & 0.12 & 0.05 & 0.05 & 0.04 & 0.06 \\
\hline Bisnis 27 - ABF Indonesia Bond & 0.17 & 0.12 & 0.11 & 0.11 & 0.12 \\
\hline JII - ABF Indonesia Bond & 0.02 & -0.07 & -0.07 & -0.08 & -0.06 \\
\hline Sri Kehati - ABF Indonesia Bond & 0.27 & 0.26 & 0.26 & 0.25 & 0.26 \\
\hline
\end{tabular}

Source: own analysis

\section{Portfolio Performance in Equity Market Downturn}

From the historical value back-testing, monthly return from 2009 - April 2020 of the Risk Parity portfolio will be compared with IDX Composite (IHSG) to see if Risk Parity can give protection from equity market downturn to the investor. Rebalancing for the risk parity portfolio done in a yearly basis. Total negative monthly return is 44 months. For 34 times of the cases, Risk Parity perform better than IDX Composite (IHSG) and for 10 times of the cases, Risk Parity perform worse than IDX Composite (IHSG). From that historical data, Risk Parity offered protection to the equity market downturn in $77.3 \%$ of the cases.

\section{CONCLUSIONS}

Majority of the actively managed mutual funds hardly able to outperform the index benchmark. 94\% of actively managed equity mutual funds underperform IDX Composite (IHSG) and $97 \%$ of actively managed fixed income mutual funds underperform Indonesia Composite Bond Index (ICBI). From those facts, using risk parity framework in passively managed index fund is a better solution compared to actively managed mutual funds that have more exposure to underperforming and mismanagement risk.

Risk parity framework offers better risk-adjusted return indicated by a higher Sharpe ratio value compared to commonly used asset allocation in the world. All four index combinations resulted in better Sharpe Ratio. Risk Parity portfolio also offered protection to the equity market downturn in $77.3 \%$ of the case from negative monthly return for equity market happened during 2009 - April 2020.

\section{REFERENCES}

[1] Aldin, Ihya Ulum, 2020, IHSG Rontok 28\% Selama Kuartal I karena Saham-saham Ini, Katadata.co.id. Available from https://katadata.co.id/berita/2020/04/02/ihsg-rontok-28-selamakuartal-i-karena-saham-saham-ini.

[2] Bodie, Zvi; Kane, Alex; Marcus, A., 2018, Investments (11th edition), New York: McGraw-Hill Education.

[3] Chandrasekhar, Rohan, 2009, Fixed-Income Portfolio Optimization, unpublished document.

[4] Dalio, Ray, 2004, Engineering Targeted Return \& Risks, Bridgewater Associates, LP. Available from https://www.bridgewater.com/resources/engineering-targeted-returnsand-risks.pdf.

[5] Indonesia Central Securities Depository, 2019, Pencapaian KSEI Tahun 2019: Implementasikan Tonggak Sejarah Baru Pasar Modal Indonesia. Available from https://www.ksei.co.id/files/uploads/press_releases/press_file/idid/175_berita_pers_pencapaian_ksei_tahun_2019_implementasikan_t onggak_sejarah_baru_pasar_modal_indonesia_20200123103744.pdf.

[6] Indonesia Stock Exchange, 2019, Laporan Tahunan 2018 Towards the Journey of Excellence. Available from https://www.idx.co.id/media/7355/2018.pdf [Accessed on 24 March 2020].

[7] Indonesia Stock Exchange, 2020, IDX Stock Index Handbook v1.1, $\begin{array}{llll}\text { Indonesia Stock } & \text { Exchange. Available from }\end{array}$ 
https://www.idx.co.id/media/8572/idx-stock-index-handbook-_-v11-desember-2019.pdf.

[8] Kazemi, H., 2011, An Introduction to Risk Parity, Alternative Investments Analyst Review, September 2011, 1: 20-31.

[9] Legg Mason, 2019, Legg Mason Global Investment Survey 2018 , Legg Mason Global Asset Management. Available from https://www.leggmason.com/en-au/campaigns/global-investmentsurvey-2018.html.

[10] Liu, Berlinda. 2020, SPIVA U.S. Year End 2019, S\&P Dow Jones Indices. Available from https://us.spindices.com/documents/spiva/spiva-us-year-end2019.pdf?force_download=true.

[11] McKinsey \& Company, 2014, The evolving Indonesian consumer Available from https://www.mckinsey.com/ /media/McKinsey/Business\%20Function s/Marketing\%20and\%20Sales/Our\%20Insights/The\%20evolving\%20 Indonesian\%20consumer/Indonesia\%20Consumer\%20Report\%20201 4.ashx

[12] McKinsey \& Company, 2013, Understanding the diversity of Indonesia's consumers. Available from https://www.mckinsey.com/featured-insights/asiapacific/understanding-the-diversity-of-indonesias-consumers.

[13] Nurdiana T., 2019, 2019, OJK suspensi produk dari 37 manajer investasi, berikut daftar dan sebabnya, Kontan.co.id. Available from https://investasi.kontan.co.id/news/2019-ojk-suspensi-produk-dari-37manajer-investasi-berikut-daftar-dan-sebabnya?page=all.

[14] O'Dea, Christopher, 2018, AQR: Risk-parity reasoning, IPE Magazine. Available from https://www.ipe.com/aqr-risk-parityreasoning/10028273.article.

[15] PR Newswire, 2017, Wealth in Indonesia: HNW Investors 2017, PR Newswire Association LLC. Available from https://search.proquest.com/docview/1916009985 ?accountid=31562.

[16] Prince, Bob, 2011, Risk Parity is About Balance, Bridgewater Associates, LP. Available from https://www.bridgewater.com/resources/risk-parity-is-aboutbalance.pdf.

[17] Roncalli T., 2013, Introducing Expected Returns into Risk Parity Portfolios: A New Framework for Tactical and Strategic Asset Allocation, Munich Personal RePEc Archive, 49821:1.

[18] Verloop, Oldrik, 2011, Risk Parity: Taking risk parity a step further, IPE Magazine. Available from https://www.ipe.com/risk-paritytaking-risk-parity-a-step-further/40034.article.

[19] World Bank, 2019, The World Bank In Indonesia. Available from https://www.worldbank.org/en/country/indonesia/overview.

[20] Zilbering, Yan; Jaconetti, Colleen M.; Kinniry Jr, Francis M., 2015, Best Practices for Portfolio Rebalancing, Vanguard Research. Available from https://www.vanguard.com/pdf/ISGPORE.pdf.

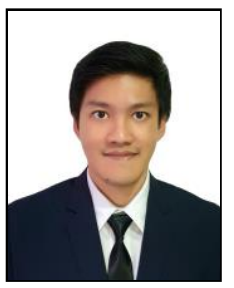

Wayan Mahendra Kurniawan, S.T. was born in Denpasar, $5^{\text {th }}$ of October 1990 . He earned his bachelor's degree in industrial engineering from Mercu Buana University, Jakarta. He continued his postgraduate education in Strategic Marketing Executive Business Administration at Bandung Institute of Technology, Indonesia

He has work experience as QC Assistant Manager at PT. Trias Indra Saputra during 2013 - 2017 and Marketing Manager at PT. Legrand Indonesia and PT. Trias Indra Saputra since 2017. He specialized in B2B marketing strategy and developed a personal interest in Indonesia Capital Market and personal finance.

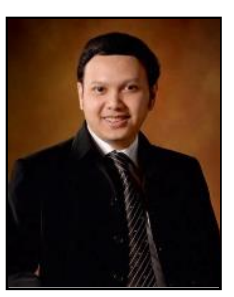

DR. (Cand) Erman Arif Sumirat, SE, MBus (Finance), CRP, CSA Ak. graduated from Universitas Padjadjaran in Accounting and Master of Business Banking and Finance from Monash University Melbourne under Australian Development Scholarship passed with distinction grade.

He has work experience in Arthur Andersen, Ernst and Young, as well as Accenture (Andersen Consulting) in the area of consulting for corporate finance. He has served to tech at MBA ITB, SBM ITB since 2005 in the area of finance and risk management. He also one of Major of Bandung (Ridwan Kamil)'s adviser in the area of financial management, infrastructure feasibility study, restructuring, risk management, and investment. He also a corporate trainer for strategy and financial management for PT. Bank Jabar Banten Tbk. 